\title{
TESOL and IATEFL
}

are co-sponsoring a 1987 Summer Institute in Barcelona in collaboration with

* ESADE (Barcelona)

* Teachers College Columbia University (N.Y.)

* University of London Institute of Education

Course Directors:

John Fanselow

Peter Strevens

H.G. Widdowson

For further information:

E.P. Mills, ESADE

Av. de Pedralbes, 60

08034 Barcelona

(Tel. 93- 20364 04)

\section{AILA SYDNEY 1987}

8th World Congress of Applied Linguistics

VIIle Congrès Mondial de Linguistique Appliquée

University of Sydney, Australia

16-21 August 1987

For information write to:

Department of Linguistics

University of Sydney

NSW Australia 2006 


\section{IRA工}

\section{International Review of Applied Linguistics in Language Teaching}

ISSN 0019-042X

Editors: Prof. Dr. Bertil Malmberg, Lund; Prof. Dr. Gerhard Nickel, Stuttgart Assistant Editor: Dr. Dietrich Nehls, Stuttgart

Since its foundation in 1963, IRAL has tried to reflect the worldwide upsurge of interest in speech communication and the rethinking of the premises of language teaching. The aim has been, and will continue to be, to provide a common meeting ground for researchers concerned with applied linguistics in its various forms.

IRAL is published quarterly. (February, May, August, November). Each annual volume contains an average of ca. 360 pages.

$\begin{array}{ll}\text { Subscription per volume } & \text { DM 140,- (Institutions) } \\ & \text { DM 98,- (Individuals) } \\ \text { Single copies } & \text { DM 36,- } \\ \text { Postage added } & \end{array}$

IRAL is obtainable in:

Austria from Gerold \& Co., Booksellers, Graben 31, A-1011 Wien, Austria

Afghanistan, Australia, Burma, Canada, Ceylon, Cyprus, Egypt, Ethiopia, Gambia. Ghana, Gibraltar, Great Britain, Greece, Hong Kong, India, Indonesia, Iran, Israel, Japan, Jordan, Kenya, Kuweit, Lebanon, Libya, Malawi, Malaysia, Malta, New Zealand, Nigeria, Pakistan, Philippines, Rhodesia, Sambia, Saudi-Arabia, Sierra Leone, Singapore, Somalia, South Africa, South Korea, Spain, Sudan, Syria, Tanzania,Thailand, Turkey, Uganda, USA, Yemen from Journals Department, Oxford University Press

Walton Street, Oxford OX 2 6DP. England

all other countries from

\section{JULIUS GROOS VERLAG P. O. Box 102423 - D.6900 Heldelberg 1}




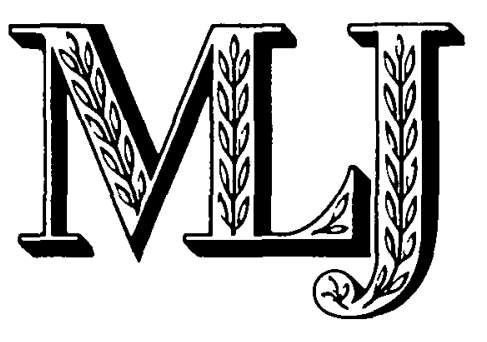

\section{The Modern Journal}

Founded: 1916

Editor: David P. Benseler

Dept. of German

Ohio State University

Columbus, $\mathrm{OH} 43210$

. . is recognized throughout the world as the outstanding foreign language/pedagogical research journal in the United States. This popular journal was founded in 1916 by the National Federation of Modern Language Teachers Associations. Topics covered in MLJ include teaching strategies, bilingualism, applied linguistics, teaching of literature, study abroad, innovative foreign language programs, and developments in curriculum, teaching materials, and testing and evaluation.

ISSN 0026-7902

Published quarterly at The University of Wisconsin Press

Subscribe now, or recommend a subscription to your library. A detailed brochure will be sent upon request.

\section{RATES}

Individuals: $\$ 13 / \mathrm{yr}$.

(must prepay)

Institutions: $\$ 30 / \mathrm{yr}$.

Foreign subscribers add $\$ 5.50 / \mathrm{yr}$.

for regular postage, or $\$ 15 / \mathrm{yr}$.

for Airmail delivery.
REPLY TO

Journal Division

The University of Wisconsin

Press

114 North Murray Street

Madison, Wisconsin 53715

USA

(608) 262-4952 


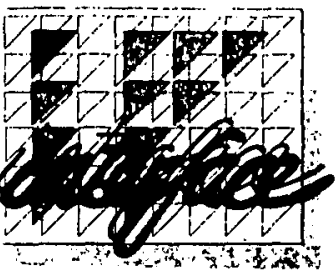

VLAAMSE ECONOMISCHE HOGESCHOOL

Department of translation and interpretation

Ginestestraat 11, 1210 BRUSSELS

presents

\section{INTERFACE}

Tijdschrift voor toegepaste linguistiek Journal of applied linguistics

JITORIAL BOARD Fred Van Besien, José Cajot, Jenny Michiels, Katja Pelsmaekers, Paul Valvekens, Jan Vanhoucke, Walter Verschueren

$\begin{array}{ll}\begin{array}{l}\text { JVISORY BOARD } \\ \text { Wim De Geest }\end{array} & \text { (Brussels) } \\ \text { Marcel De Grève } & \text { (Ghent) } \\ \text { L.K. Engels } & \text { (Louvain) } \\ \text { Guido Geerts } & \text { (Louvain) } \\ \text { René Haeseryn } & \text { (Antwerp) } \\ \text { Pierre Hessmann } & \text { (Antwerp) } \\ \text { Odo Leys } & \text { (Louvain) } \\ \text { Jos Nivette } & \text { (Brussels) } \\ \text { Marc Spoelders } & \text { (Ghent) } \\ \text { Fernand Vandamme } & \text { (Ghent) } \\ \text { Dominique Willems } & \text { (Ghent) }\end{array}$

$\begin{array}{lr}\text { Cristina Bacchilega } & \text { (Manoa) } \\ \text { René Dirven } & \text { (Duisburg) } \\ \text { André Lefevere } & \text { (Austin) } \\ \text { Marylin Gaddis Rose } & \text { (Binghamton) } \\ \text { Stefano Rosso } & \text { (Verona) } \\ \text { Pieter A.M. Seuren } & \text { (Nijmegen) } \\ \text { Raymond van den Broeck } & \text { (Amsterdam) }\end{array}$

TERFACE is a journal of applied linguistics. in a broad sense. Contributions will. deal. with native and foreign language teaching, contrastive linguistics, error analysis, translation and translation theory, interpretation, terminology, lexicography, stylistics, pragmatics, discourse analysis, psycholinguistics, etc.

Each issue will feature articles, book reviews and announcements of conferences and seminars.

NGUAGES Dutch, English, French and German

EQUENCY Interface will appear twice a year (Fall and Spring).

The first issue is scheduled for November 1986

NUSCRIPTS (approx. 15 pages typewritten) and books for review should be sent to the chiefeditor: F. Van Besien, Vlaamse Economische Hogeschool, Ginestestraat 11, B.1210 Brussels (Belgium).

3SCRIPTION RATES Belgium: $300 \mathrm{BF}$, Other countries: $350 \mathrm{BF}$. Payable to post office account no. 000-0806991-48, Vlaamse Economische Hogeschool, Koningsstraat 284, B.1210 Brussels (Belgium)

\section{TURN TO INTERFACE \\ Vlaamse Economische Hogeschool \\ Ginestestraat 11 \\ B.1210 Brussel (België)}

VE:

JRESS:

Y:

ZIP CODE:

INTRY:

is further information about INTERFACE 


\section{NOTES FOR CONTRIBUTORS}

Contributions. Contributions are welcomed from all countries. They should be written in English. All articles, as well as books for review and listing, should be sent to: Albert Valdman, Editor, Studies in Second Language Acquisition, Ballantine Hall 602, Indiana University, Bloomington, IN 47405.

Manuscripts. SSLA requires that all submissions conform to the requirements of the Publication Manual of the American Psychological Association (Third Edition) which can be obtained from the Order Department, American Psychological Association, 1200 17th St., N.W., Washington, D.C. 20036. It is also available in many bookstores and libraries.

All manuscripts of articles should be submitted in four copies, two copies for book reviews. No materials will be returned to authors unless postage is provided. Contributors should keep a copy of the manuscript; the original manuscript will not be included along with galley proof. All submissions must be typewritten, doublespaced, on standard-size paper, 8 1/2 $\times 11$ inches. Provide a separate title page including the following information: the title; the subtitle; and the author's name and affiliation. These items must each be entered on separate lines, double-spaced, using normal capitalization and no underscoring. Each paper must begin with a 100-150 word abstract.

Tables, figures, and illustrations. Authors are responsible for providing camera-ready copy of tables, figures, and illustrations with the submission of an article. Authors should be prepared to furnish such copy within two weeks after notification by SSLA that their article has been accepted for publication.

References. Research referred to should be listed in full in a bibliography at the end of each article, research note, review article, or book review following the specifications of the Publication Manual of the American $P$ sychological Association. Brief citations should be made in the text by listing the author's surname, the publication date, and page number(s) when pertinent (e.8., Cass, 1973; Chomsky, 1974, p. 240). When the author's name is part of the text, follow this form: Gass (1983) argues that ...

Begin the bibliography on a separate page entitled "References." The bibliography must be double-spaced throughout. Each entry is to include the following: author's name, co-authors, if any, publication date, title of work. For journal articles, also provide the journal's name, volume number, and page numbers for the article. For an article in a collection, list the editor's name, the title of the collection, and the page numbers of the article. For books and monographs, list the edition, volume number, series, place of publication, and name of publisher. Punctuate as in the following examples:
Ard, J. (1983). Towards an applied phonology. Paper presented at the Conference on the Uses of Phonology, Southern Illinois University, Carbondale.

Bialystock, E. (1978). A theoretical model of second language learning. Language Leaming, 28, 169 183.

Cole, R. A. (Ed.). (1980). Perception and production of fuent speech. Hillsdale, NJ: Lawrence Erlbaum.

Krashen, S. (1978). The monitor model for adult second language acquisition. In R. C. Gringas (Ed.). Second language acquisition and foreign language leaching (pp. 1-26). Artington, VA: Center for Applied Linguistics.

Krashen, S., \& Terrell, T. (1983). The natural approach. New York: Pergamon.

Plann, S. (1976). The Spanish immersion program: Towards native-like proficiency or a classroom dialect? Unpublished master's thesis, University of California, Los Angeles.

Book reviews. Begin each book review with a separate title page including a full citation of the work under review and the author's by-line. The citation is to be doublespaced and must include the title of the work, the edition (if not the first), the name of the author or editor, the place, publisher, and date of publication, and the pagination. The by-line stands below the citation after a quadruple space. It contains the words "Reviewed by" followed by the reviewer's name and affiliation. Review articles should be titled; reviews, however, are not to be titled. For example:

A foundation course for language teachers. Tom McArthur. Cambridge University Press, 1983. Pp. 192.

Reviewed by Albert Valdman, Indiana University

Proofs. First proofs will be sent to the author (or a nominee), who will be expected to correct them and return then to the Editor, by airmail where appropriate, within three days of receipt.

Offprinte. 25 offprints of both articles and review articles will be provided free of charge. Additional offprints may be purchased only if ordered at proof atage.

Submission of an article is taken to imply that it has not previousty been published or is not being considered for publication elsewhere. If an author is publishing a related article elsewhere, this fact should be stated.

Copyright. Contributors of accepted articles will be asked to assign their copyrights on certain conditions to Cambridge University Press to help protect their material, particularly in the U.S.A. 


\section{Studies in Second Language Acquisition Volume 9 Number 1 February 1987}

\section{ARTICLES}

Interlanguage Variability in Narrative Discourse: Style Shifting in the Use of the Past Tense Rod Ellis

The Expression of Temporality in Basilang Speech

John H. Schumann

The Use of Verbal and Imagery Mnemonics in Second-Language

Vocabulary Learning Andrew D. Cohen

Phonological Similarity, Markedness, and Rate of L2 Acquisition

Roy C. Major

Curricular and Extra-Curricular Factors in Multilingual Education

Alex Housen and Hugo Baetens Beardsmore

\section{REVIEW ARTICLE}

Introductions to Linguistics for Second Language Acquisition Specialists Kathleen Bardovi-Harlig

Revicws, Book Notices, Publications Received

\section{CAMBRIDGE UNIVERSITY PRESS}

The Pitt Building. Trumpington Street, Cambridge CB2 IRP, England 32 East 57th Street, New York, NY 10022, U.S.A.

10 Stamford Road, Oakleigh, Melbourne 3166, Australia

(C) 1987 Cambridge University Press

Printed in the United States of America 